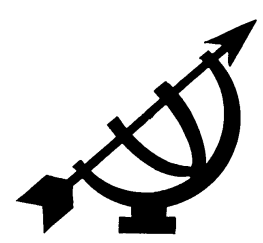

\title{
Learner discipline in South African public schools - a qualitative study
}

\author{
J.P. Rossouw \\ School for Education and Training \\ Faculty of Educational Sciences \\ Potchefstroom University for CHE \\ POTCHEFSTROOM \\ E-mail: soojpr@puknet.puk.ac.za
}

\begin{abstract}
Learner discipline in South African public schools - a qualitative study

Recent research has shown that the involvement of youth in the liberation struggle which ended in 1994 caused them to develop arrogance towards adults, that is, both educators and parents. Another reason for the decline in the level of discipline in recent years might be the overemphasis on human rights, especially children's rights, in reaction to the increase in child abuse or the lack of a human-rights culture in the apartheid era.

A lack of learner discipline may seriously hamper the teaching and learning process, and, if disruptive behaviour prevails, education cannot be successful. This article focuses on educators' positive and negative reactions to learner misconduct in South African public schools, as revealed by qualitative data gathered by means of interviews, as part of a national research project on learner discipline. Fourteen schools were visited by a group of researchers and field workers, during which principals, other educators and learners were interviewed.
\end{abstract}

Special reference is made to forms of learner misconduct that have the most prominent influence on discipline, possible causes of these, and preventative or proactive measures taken by educators to restore or maintain learner discipline. Value-driven approaches to discipline and to approaches that might be educationally unsound, are also incorporated. All the mentioned approaches are evaluated from within a reformational framework. 
Opsomming

Leerderdissipline in Suid-Afrikaanse openbare skole - 'n kwalitatiewe studie

Onlangse navorsing het getoon dat die betrokkenheid van jeugdiges by die apartheidstryd wat in 1994 geëindig het, veroorsaak het dat hulle 'n arrogansie ontwikkel het teenoor opvoeders sowel as teenoor ouers. Nog 'n rede vir die afname in die vlak van dissipline die afgelope paar jaar mag die oorbeklemtoning van menseregte wees, veral die regte van kinders, in reaksie tot die toename in kindermishandeling of die afwesigheid van 'n menseregtekultuur in die apartheidsera.

'n Gebrek aan leerderdisspline mag die onderrig- en leerproses ernstig benadeel. Indien ontwrigtende optrede voorkom, kan onderwys nie suksesvol wees nie. Hierdie artikel fokus op positiewe en negatiewe reaksies van opvoeders op leerderwangedrag in SuidAfrikaanse openbare skole, soos aangetoon deur kwalitatiewe inligting verkry uit onderhoude tydens 'n nasionale navorsingsprojek oor leerderdissipline. Veertien skole is besoek deur 'n groep navorsers en veldwerkers, waartydens onderhoude gevoer is met skoolhoofde, ander opvoeders en leerders.

Die artikel bevat spesiale verwysing na daardie vorme van leerderwangedrag wat die grootste invloed op dissipline het, na moontlike oorsake van die gedrag, en na voorkomende of proaktiewe optrede deur opvoeders met die oog op die handhawing of herstel van leerderdissipline. Waardegedrewe benaderings tot dissipline en benaderings wat moontlik onopvoedkundig is, word ook geïnkorporeer. Al hierdie benaderings word geëvalueer vanuit 'n reformatoriese raamwerk.

\section{Introduction}

Currently one of the most prominent factors influencing the learning environment in South African schools is the conduct of learners. In an education system that is still struggling to create a culture of teaching and learning, ill-disciplined behaviour can cancel all wellintended efforts to restore or create this culture. Andrews and Taylor (1998:1) point out that students who misbehave tend to perform poorly in school and tend to be absent frequently from school. They further state that "in addition, discipline at school is correlated with student absenteeism". In recent research in South Africa related to school discipline, Moloi (2002:2) mentions that "the learners lost a culture of respect and trust towards the educators". Learner safety, security and success in education is often adversely affected by disruptive behaviour or other forms of misconduct by fellow learners. 
This article explores the positive and negative reactions by educators to learner misconduct in South African public schools, as revealed by the findings of a research project on learner discipline. Special reference is made to forms of learner misconduct that have the most prominent influence on discipline, possible causes of these, preventative or proactive measures taken to restore or maintain learner discipline, value-driven approaches to discipline and approaches that might be educationally unsound. The problem of learner misconduct as well as the problem of devising methods for restoring or maintaining learner discipline will be approached from a reformational perspective, i.e. a perspective informed by the Bible as the Inscripturated Word of God. In view of this, the following strategy will be followed in this article. The first step will be to reflect principially on the reformational view of the child and his (her) upbringing and education. This will be followed by a brief discussion of a possible root cause of learner misconduct from a reformational point of view. A brief exposition of the empirical research design and of its results will then follow. The results of the survey will then be discussed from the perspective of the principial or fundamental view of a child and his/her education. In conclusion, attention will be drawn to measures that can be taken on the basis of a reformational-educational point of view to maintain and/or restore discipline in schools.

\section{Problem statement}

In the introductory article to this volume regarding a principial foundation for authority, freedom, order and discipline, the author mentions the effect of a postmodern outlook on life, in which the quest for personal freedom and autonomy, as well as an unwillingness to be subjected to the force and power of any superior order or discipline, are the main characteristics. He mentions that the postmodern person refuses to sacrifice his or her freedom just to fit into a "grand narrative" (Van der Walt, 2004). Such an approach will obviously lead to fundamental differences between those who should be subjected to discipline, the learners, and the authorities that have the duty to maintain order in schools - the principal, staff and (in extreme cases) the governing body of the school.

As will be indicated in some detail in this article, a lack of discipline may seriously hamper the teaching and learning process, and few ideals for education can be realised if disruptive behaviour prevails. The importance of positive discipline as the cornerstone of the creation and maintenance of a positive learning environment in schools cannot be ignored. Research by Nxumalo (2001:77) 
indicates the need for both learners and teachers to be disciplined for effective functioning of schools. According to Nxumalo, discipline is vitally important for teaching and learning in class to be effective.

Discipline problems can be defined as "disruptive behaviour that significantly affects fundamental rights to feel safe, to be treated with respect and to learn" (Mabeba \& Prinsloo, 2000:34). Although it is a serious problem in this country, discipline problems are, as can be expected, not limited to the South African public school system. Van Wyk (2001:196) points out that "the prevalence and gravity of discipline problems in schools is a universal concern". She also states that the worldwide reaction to these problems is the increased use of reactive and punitive strategies. Some of these strategies are not effective or educationally sound, a point of view which necessitated the national research project on which this article reports.

The extent and seriousness of learner misconduct in South Africa should not be underestimated. Research by Maree (2000:1) highlights that some South African schools "are increasingly beginning to resemble war zones. It has become clear that all schools are not free to teach and all pupils are not free to learn".

In an attempt to determine the causes of the increase in illdisciplined behaviour, Moloi (2002:2) states that the involvement of the youth in the liberation struggle which ended in 1994 caused them to develop "arrogance towards adults, that is, both the educators and the parents". Some causes of violence in schools are mentioned by Maree (2000:4): gang activities, the lack of transformation, learners carrying guns and smoking dagga, the lack of counselling services, the intolerance of school management towards some groups, and parental apathy.

This observation is supported by the earlier findings of Reddy (1996: 50) who mentions that there is a serious and widespread discipline problem in schools. "Insubordination, drugs, alcoholism, corruption, bribery, vandalism, violence and gangsterism are becoming difficult to control".

A major problem like ill-discipline in a school system seldom prevails due to one or two reasons only. As can be expected, an overemphasis on rights and a negative attitude on the part of learners are not the only causes of current discipline problems. In malfunctioning schools, where a culture of learning and teaching is absent, educator misconduct may also have a negative effect on learners' behaviour. Poorly qualified and incompetent teachers and 
"work-to-rule" attitudes of teachers can exacerbate the problem (Reddy, 1996:50).

In the last part of the article a number of factors related to the problem of a lack of discipline, and the accompanying lack of effective disciplinary measures in many schools, will be discussed. An attempt will be made to provide, from an analysis of the empirical data, answers to the following questions:

- Which forms of misconduct have the most prominent influence on school discipline?

- Which internal and external causes can be identified for the misconduct?

- Which educationally unsound measures are used?

- Which proactive, preventative measures can be successfully implemented by educators to positively influence the learning environment?

\section{The aim of the article}

The purpose of this article is to analyse the phenomenon of learner misconduct in South African schools. The analysis will be based on the existing corpus of knowledge on the subject as well as on a reformational perspective on phenomena such as the reformational view of the child, misconduct by learners and of measures that can be taken to restore and maintain discipline in the context of the school.

\section{A reformational view of the child, discipline, mis- conduct and the restoration of discipline}

One cannot analyse phenomena such as the child (learner), discipline, learner misconduct and the restoration or maintenance of discipline in a religious vacuum, i.e. without a normative framework. Such a normative framework is founded on a particular set of religious (or even ideological) convictions and (pre-)suppositions, which in turn reveal the life-conceptual (cosmoscopical) views and convictions behind them. The views about the child (learner), education, discipline, misconduct and so forth expressed later, have been informed by a reformational life-view, implying that Biblical perspectives and principles will be invoked wherever possible. The discussion will, however, be restricted to only a few of the more succinct aspects of the theme under discussion: the child as learner 
(childview), education and discipline, and measures that can be taken to combat misconduct and to restore discipline.

\subsection{The child (learner)}

The investigation underlying this article focused on children and the lack or loss of discipline among them. This begged the question: Who and what is the child? The obvious answer is that a child is a person, a human being that is still in the process of developing and unfolding towards the status of full maturity. The important point here is that a child is a complete human being. In view of this, all the aspects of a reformational anthropology is applicable to the child (cf. Van der Walt, 1994:153 et seq. for a detailed discussion of the reformational view of man). Children, like all human beings, are creatures created by the hand of God; creatures who are still searching for self-identity, gifts of God to their parents. The birth of a child places great responsibilities on the shoulders of all its educators, including the parents and the teachers. A child is also a duality of sexes, a holistic being, image of God, a sinner, a fellow human being, a redeemed person in Jesus Christ, a creator of culture - and much more. It is impossible to discuss every aspect of a reformational anthropology within the constraints of an article. The important point is, however, that educators have to reckon with the totality of a reformational anthropology (including childview) when reflecting on the problem of misconduct and other forms of inadequate discipline in schools. Although children are complete human beings, the following can be said of them in particular: the child is a human being in the process of developing towards adulthood; to be a child is to be something unique - being a child is totally different from being an adult. A child is a person who is dependent on others, such as his or her parents and other, secondary, educators, and will remain so for a relatively long time. In a sense, a child is still "incomplete", a potential adult. Childhood has intrinsic value; the period of youth is irreplacable. The Bible also refers to childhood as a particular mode of being human.

\subsection{The need for education}

The core feature of childhood is that the child remains dependent on education for the purpose of reaching adulthood. Education is possible because God has created human beings not only to educate others, but also to be able to be equipped themselves through education for the challenges of adulthood. Education is also necessary since the child would otherwise not have been able to grow to the status of adulthood: the child would not have been able 
to be guided, formed, equipped, enabled and disciplined for the task of responding to his or her calling to serve God and his or her fellow human being. The need for education, say Vogelaar and Bregman (1983:97), is what childhood adds to being human. Education does not make human beings, but helps form and change them into adults. The kind of education that a child receives is determined by the societal relationship in which the child finds itself. (In this discussion, the societal relationship in question is the school. Education and discipline in schools differ in several respects from those in parental homes.) The nature of the discipline to which a child is subjected is also determined by the personality traits of the particular child. A child does not arrive in this world as a tabula rasa, but rather as a person with potential which has to be unfolded through education.

Fowler, Van Brummelen and Van Dyk (1993:157 f.f.) describe the educational process involved in schooling as follows: Firstly, it means guiding the child to follow a certain direction, and not another. This guidance has to be maintained until such a time that the child has become enabled to choose for him- or herself a life of service to God and fellow human beings. Secondly, it amounts to unfolding, in a double sense. On the one hand, reality has to be unlocked or unfolded for the child; on the other, the child has to be unlocked and unfolded for the purpose of understanding his or her task in creation. Thirdly, education is nothing else than enabling the child towards discipleship.

\subsection{The problem of misconduct and deviant behaviour on the part of the child (educand)}

Educators have to reckon with the presence of $\sin$ in reality. According to the Bible, the child is not naturally inclined to be good and innocent in the presence of God and his or her fellow human beings. This explains the presence of misconduct, deviant behaviour and disciplinary problems in the lives of human beings in general, and of children in particular. It is, therefore, not wise to educate according to the "nature" of the child or to allow the "natural potential or aptitude" of the child to run its "natural course". Despite the fall into sin, human beings remain human beings; the child remains a human being, and this is why education remains possible. A child remains educable, despite the ravages of $\sin$ in this world. The notion of educability acquires deeper meaning when it is viewed in light of the conviction that education is not only required to help children become mature adults, but also, and particularly, to equip children for their service of God and fellow human beings, based on 
their love for God and fellow human beings (Vogelaar \& Bregman, 1983:98).

\subsection{Discipline or discipleship}

Discipline refers to disciple- or followership. To enable the child, according to Fowler, Van Brummelen and Van Dyk (1993:160), is to provide a learner with the skills required, and to help a child to be prepared to act as a responsible and effective disciple (follower) of the Lord in this world. This is the final purpose of education (also in the context of the school). Learners should be guided by means of unfolding for the purpose of enabling them to become true disciples. According to Van Brummelen (1988:2), it is the main function of the school to guide and enable a child for a life of responsible discipleship in Jesus Christ. (Like all compact statements, this one is full of implications; space does not allow a broader discussion, however.) Disciple- or followership, the term to which "discipline" refers, amounts to the following. A disciple, i.e. a disciplined person, is - according to a Biblically-founded perspective - a person who does not only possess the wisdom to hear the Word of God (His will, His laws for creation), but also understands His Word and is prepared to act accordingly. A disciple is a person who is prepared to serve God and his or her fellow human being, inter alia by combating sin in this world (Van Dyk, 1997:40; Van Dyk, 2000:64).

The findings of the empirical research conducted and forming the backdrop of this article, will be evaluated against this fundamental view of the child, education and learner (mis)conduct.

\section{Research method and data gathering process}

The research project on discipline that was conducted by the Graduate School of Education at the Potchefstroom University for $\mathrm{CHE}$ consisted of a research design that included qualitative as well as quantitative research methods, and both were utilised in a South African phase as well as an associated international phase. One hundred and four schools, from all the provinces in South Africa, volunteered to take part in the project. This article reports only on the outcomes of the qualitative data gathered in the South African phase.

Since the 1980s qualitative research has developed rapidly as a method for research in the social sciences and especially in education sciences (Burgess, 1985:4). The primary purpose of this method, according to Borg and Gall (1989:23), is to understand the 
facts that form the basis of a certain phenomenon. This method has a number of advantages, among which the following are the most prominent:

- In-depth understanding of the situation and meaning for those involved (Henning, 2004:41).

- Lived experience and deeply held beliefs or feelings cannot truly be determined through quantitative survey questionnaires, in which the set number of items are expressed in predetermined language, formulated by the researcher (Henning, 2004:34).

Qualitative research is an effort to avoid the imposition of a previous theory or hypothesis upon the subjects of the research (Lemmer, 1991:7). Participants can narrate their experience more efficiently when asked to do so in their own words in interviews (Henning, 2004:37).

The selection of the participants is of crucial importance in qualitative research, because each respondent has access to unique information (Goetz \& LeCompte, 1984:215). No respondent can offer universal information. In qualitative studies researchers normally use a relatively small selection from the total population (Bogden \& Biklen, 1982:2), unless the researcher sends a large number of field workers to most of the population, as in certain large-scale interview surveys. The validity of the findings is not so much dependent upon the number of respondents than on the knowledge and the level of reliability in which the respondents react to the questions during the interviews. The quality of the data analysis obviously also directly contributes towards the validity. Carey (1984:75) mentions that experienced researchers have found that, after intensive questioning of about eight respondents, a point of saturation has been reached regarding certain information. This data might open the door to new topics and themes that demand "snowball sampling", during which, according to Henning (2004:71), new respondents are approached to clarify certain aspects that emerged during the initial interviews.

A focus group session, which is a variation of the individual interview, creates unique opportunities for qualitative inquiry and is regularly used as research method. The focus group normally consists of four to eight participants, with different points of view, and the researcher acts as facilitator of the discussion. Their interaction leads to in-depth information that is seldom obtained during individual interviews. 
Fourteen schools situated in the North West Province, Free State Province, Western Province and Eastern Province (see Appendix A) were visited by a group of researchers, during which the principals, other educators and learners were interviewed individually or in focus groups. These schools were selected from those schools that volunteered to take part. The majority were approached to take part because of previous personal contact between the principal and the researcher, and they also had to be situated conveniently to fit into the research tour program. Those in the North West Province were selected because they were within reaching distance from the University for a single-day excursion of the field-worker group. A balance was struck between secondary schools (eight) and primary schools (six), as well as those schools in socio-economic affluent areas and those in previously disadvantaged communities. Some schools were situated in rural and others in suburban areas or in large towns. This way of selection ensured a diversity of cultural and ethnic groups among learners as well as educators.

The interviews with educators and focus-group sessions with learners provided a broad perspective of most aspects related to this theme. Informal observations and unstructured discussions at some of the schools also served as an additional source of perspectives and insights. Most of the interviews and focus-group sessions were conducted and transcribed by fourteen senior under-graduate students who acted as field workers after being trained in interview techniques and in qualitative study methodology. In one focus-group session (see Appendix B) four educators from a diverse combination of suburban and rural schools, also representing different cultural groups, provided extremely valuable insights for this study. Some of the recommendations in this article are directly linked to this session, as will be indicated. Qualitative data gathered from the additional comments provided on questionnaires by some respondents who took part in the quantitative research served as an additional information source.

The final analysis and interpretation of the data were carried out by the author of this article, who was actively involved throughout the whole data-gathering process at the schools. The transcriptions were read and re-read, after which the content was coded and categorised, aided by the interview schedule that was used in all interviews (Leedy \& Ormrod, 2001:168-169). Primary patterns were identified and the final categories were established, as reported below. 


\section{Findings}

The results of research undertaken shows that a wide variety of learner misconduct has an influence on discipline in South African public schools, and there are numerous ways in which educators, principals and governing bodies attempt to cope with these. A number of coping strategies and proactive, successful methods have been identified to ensure a positive disciplinary climate, resulting in an enhanced culture of learning and teaching.

There is a vast range in the levels of orderly behaviour in South African schools, ranging from those schools where the principal and staff are totally in control, to those where disruptive learner behaviour causes completely dysfunctional schools. The majority of schools that became involved in the project still maintain a reasonable level of order and discipline, and a positive culture of teaching and learning prevails. However, most of the respondents, including learners, mention that there has been a clear decline in the level of discipline during the last five years.

The emphasis in the research project was on the positive aspects of discipline, especially to determine preventative, proactive measures and to identify the role that a value-driven approach can fulfil. This emphasis is also the approach of this article, but to create a realistic background against which the positive ideas, solutions and creative methods can be put into perspective, the following paragraphs will first touch on the negative elements - types of misconduct and the causes thereof.

\subsection{Types of learner misconduct}

Disrespectful behaviour towards educators that manifests itself in numerous forms of misconduct, is the most commonly reported problem. A lack of respect is stipulated by many educators as the underlying reason for many other forms of misconduct. Respondents at some schools report types of misconduct that can be classified as "less serious" misconduct like disobedience, tardiness, noisiness, homework not done, and refusal to keep quiet when educators want to talk. A number of learners complained that "our class mates play with cell phones at the back of the class" and "when the hero in the class aggressively confronts the teacher, everyone thinks he is cool and has a strong personality". One learner commented on the Curriculum-2005 approach where learners are allowed to talk softly: "Some of our friends grab the whole hand and make a lot of noise". Educators in other schools, however, have to cope with much more 
serious misconduct like constant absenteeism, vandalism, theft, smoking dagga, bullying, examination dishonesty, assault, exposure to pornography and gambling. Verbal assault on educators and blatant insolence are reported at many schools: "When the teachers are angry with the class, some people in our class openly laugh at them."

It should be noted that, although some forms of misconduct are clearly more serious and can even be regarded as criminal offences, all these forms do have a negative influence on a culture of teaching and learning. Some of the causes of misconduct that were identified during the course of the research project are reported in the following paragraphs.

\subsection{Causes of learner misconduct}

If the causes of misconduct are known, it will become easier for educators to find solutions. Respondents mention that there are internal as well as external causes.

\subsubsection{Overemphasis on rights}

One cause that was mentioned in numerous interviews is the overemphasis on human rights by many stakeholders. As one desperate educator put it: "Since human rights became an issue, the situation has changed dramatically." This overemphasis prevails internally - in schools - as well as externally - in homes and in the community. It manifests in the fact that many learners are very much aware of their rights, but show little responsibility to meet their obligations. Some educators at a large primary school report that "learners have too many rights" and a focus group of senior learners in a suburban high school referred to the cancellation of "proper initiation" of grade 8 learners: "This definitely leads to a lack of respect for seniors and teachers". Associated problems that an overemphasis of rights may cause, is a "don't-care attitude" and lack of insight regarding their role in the learning process. Some of these learners do not strive to excel and rather try to influence their class mates to do the same.

Unfortunately the overemphasis of rights is also visible in the educational approach of some educators and parents. Some principals are under pressure to recognise the learners' rights and do not know up to which point they should be allowed to demand more of their pupils. Educators report that they are uncertain, confused and afraid, because "I might unknowingly infringe upon 
learners' rights and be accused of misconduct". One question from a confused educator was: "May I suspend a disruptive learner from a class? He has the constitutional right to education. But what about the others who behave well?"

\subsubsection{Internal causes of learner misconduct}

Some of the prominent causes of misconduct that exist in schools themselves, as revealed in the research, are the following:

- The male-female ratio of the staff seems to have an influence on the disciplinary climate in schools, as it is evident that where there is a higher percentage of male educators, there are fewer disciplinary problems.

- Learners often have a negative influence on one another - the group often admires and imitates those individuals who are unruly and arrogant.

- Large numbers in classes cause disruptive behaviour, and some educators have difficulty in controlling large groups.

- When educators are absent from classes, lack of discipline may prevail. This absence is due to numerous reasons ranging from mere tardiness, too many co-curricular duties, and other causes including teachers' union activities during school hours and HIV/Aids-related illness.

- Human dignity is not respected by some learners, which leads to the victimisation and bullying of younger learners.

- Prescribed processes in terms of legislation pertaining to disciplinary action against learner misconduct prevent immediate strong action, that causes further disruption. Some respondents mentioned that "due process procedures that are similar to those utilised in labour relations, are inappropriate for learner discipline".

- The implementation of Outcomes-based Education may cause those learners with the inclination to misbehave to misuse the less formal atmosphere during group sessions.

\subsubsection{External causes of learner misconduct}

Many causes of misconduct originate outside the school itself. Interviews revealed that a number of serious external causes have a direct impact and negative influence on a school: 
- Many schools report that there is "a total or partial lack of discipline maintained by parents at home" and that this is one of the major reasons for disruptive behaviour in schools. Some of these parents feel helpless, as one learner observed: "Teenager parents are afraid of their children and do not want to be unpopular". Some parents expect from the teaching profession to solve their problems, despite the fact that many are apathetic towards and disinterested in school and educational matters.

- Serious, traumatic experiences such as alcohol and drug abuse, sexual abuse, exposure to pornography and assault result in disruptive behaviour at many schools.

- Principals in lower socio-economic areas report that unstable or dysfunctional homes caused inter alia by poverty, disinterested or illiterate parents, have a negative influence on school discipline. "HIV/Aids has an enormously destabilising effect", some educators added.

- Lack of care in homes across all socio-economic levels causes some learners to look for attention through misbehaviour, or to their fail to prepare homework properly.

- Bad relations with specific educators (individually or as a class group) are caused by the personality or approach of the educator. Victimisation of specific educators by groups of learners was also reported.

- The obvious decline in discipline, according to some respondents, originates in the community rather than in schools, and it does have a major influence on a school and the disciplinary climate in a school.

- Parents show a lack of tolerance and respect towards government authorities as well as educators, and some have a laissezfaire approach towards child education.

- Parents expect schools to teach their children proper conduct, but do not realise or admit their own responsibility.

\subsubsection{Discussion}

Although the respondents, both individuals and groups, mentioned several instances of learner misconduct and deviant behaviour, none of them succeeded in penetrating to the root cause of the problem, viz. the presence of sin in this world. None of them articulated the insight that disobedience was the root cause of the problem. As has been indicated in the discussion of the principles in 
which disciplined behaviour is grounded, children are not naturally inclined to be good and innocent. As indicated, education should not only take place according to the "nature" or the "natural inclinations, potential or aptitude" of learners. Education can also not be allowed to follow its "natural course". Because of man's radical break with God's will, the human being's natural inclination is to be disobedient to God and other people, including educators. This fundamental rebellion against God and His ordinances leads to a rejection of the true destination of the human being. The rebellion and disobedience has universal proportions; not a single centimetre of creation and human existence has not been affected. The rebellion comes from the human heart. The fall into sin has affected the heart which is the core of human existence. Sin has not merely weakened human capacities; it has indeed resulted in rejection of God's will and to insurrection (Schoeman, 1975:24-25). As has been said before, children remain human beings despite the ravages of sin in their lives, and as such remain highly educable. They should be educated in a loving and caring spirit. Education should form part and parcel of the redemptive work of Jesus Christ: it should embody the message of rescue from sin and of re-creation of the heart. The redemptive work of Jesus Christ is instrumental in re-creating the heart of the human being. This is the key to addressing the problem of learner misconduct and misbehaviour.

The following discussion addresses some of the measures that have been suggested by principals and other educators to improve discipline in schools.

\subsection{Preventative and proactive measures}

There are many different disciplinary measures that are implemented by the respondents. Although some schools have not suggested any specific method that can be classified under "preventative measures" and tend to resort to a punitive approach, there are positive contributions that were identified from the qualitative study.

The most basic, obvious preventative measure is the creation of a code of learner conduct, as prescribed in section 8 of the Schools Act (SA, 1996a). Regarding measures to change learners' behaviour, Maree (2000:8) suggests that his "first and foremost recommendation is the drawing up of written (and workable) school codes and rules". According to such a code all stakeholders, including learners, know exactly what kind of conduct is expected, but the existence of a code of conduct unfortunately does not guarantee proper behaviour. 
Other measures suggested by respondents are the following:

- Some of the schools that took part in the research project mentioned, among others, that the results of disciplinary cases are usually openly communicated to the rest of the learners so that they know what to expect if they disobey the rules.

- The daily school programme or activities are effectively structured so that learners know what to expect and feel secure. A strict class routine is a very effective proactive method in especially the lower primary classes. In some township schools, learners are encouraged to stay at school after classes have ended for the day and to take part in sport, drama activities, computer training, to attend extra classes or to watch satellite television. This is an attempt to keep them away from the negative elements in the community while their parents are still at work.

- The direct involvement of different role-players is one measure that has proved effective. One example is the buddy system in which learners are paired off in order to take responsibility for each other. One school reported that positive, senior learners successfully take responsibility for a younger learner with behavioural problems. One principal suggests that principals should ensure personal contact with learners by facilitating some learning experiences themselves, or travelling with them by bus to sporting events. The community may also become involved in contributing to the maintenance of discipline by supporting the positive behaviour of learners by, for example, publishing examples or stories that depict appropriate behaviour.

- The stronger sense of belonging in smaller groups may be utilised to maintain discipline. Class groups develop their own codes of conduct (officially or unofficially) and are rewarded or reprimanded in the group and as a group. This approach stands out as one of the most effective preventative measures because of the internal motivation in the group to act responsibly.

\subsection{Educationally unsound measures}

Several measures were reported that stand out as educationally unsound. Although respondents mention that these measures are quite effective in curbing ill-disciplined conduct, they are professionally questionable.

- According to many respondents the prohibition of corporal punishment has created many problems for those educators and schools that previously utilised corporal punishment (or threats in 
this regard) as their major method of maintaining discipline. Interviews with educators at schools which are situated in areas where violence and gangsterism are common phenomena, show that, for many educators, "corporal punishment is the only way with some of the boys and even some girls. You cannot earn their respect in any other way". This kind of punishment is, however, totally prohibited by section 10 of the South African Schools Act 84 of 1996 (SA, 1996a). As stated in this Act any person who contravenes this provision "is guilty of an offence and liable on conviction to a sentence which could be imposed for assault".

- At one suburban school it was reported that community service was utilised as an alternative to corporal punishment. However, this kind of punishment was abandoned after complaints by parents. Equally unacceptable is the fact that one school has red overalls in which offenders are involved in cleaning the school grounds, stairways and corridors in sight of other learners. Both these methods are humiliating and should not be practised. Nonetheless, newspaper reports confirm that cleaning schools is widely used as a disciplinary measure, although some practices such as after-hours cleaning of desks in the absence of other learners are less humiliating (Erasmus \& Joubert, 1998:10; Ngubane, 2000:5). A National Department of Education publication dealing with alternatives to corporal punishment (DOE, 2000:25), suggests that community service and performing menial tasks like "tidying up the classroom" are acceptable. Nonetheless, one principal argued this could be regarded as being against the constitutional prohibition of exploitative childlabour practices as enshrined in section $28(e)$ of the Constitution (SA, 1996).

- A commonly used method is a system according to which a learner can gain credit points or lose points on a discipline scale. Every learner receives a number of points at the beginning of each term, and more serious disciplinary action is taken when the points drop below a certain level. Offences are recorded accumulatively, filed and are used to determine a proper sanction when there is either a serious offence or too many minor offences. Although this can be regarded as a positive, fair way of disciplining learners, educators at various schools complain about the amount of paper work. Moreover, the serious question can be asked about the fairness of using a system where the offences are filed permanently, and can be used against a learner long after he or she has been found guilty of a specific offence. In one primary school this is called the "blue card system", and they 
even send this file to the secondary school where the learner enrols after grade 7 . It can be argued that this approach is basically educationally unsound and that it provides no motivational value. The disciplinary approach used with educators, as specified in Schedule 2 (4) (4)(e) and (5)(e) of the Employment of Educators Act 76 of 1998 (SA, 1998), is to destroy filed written warnings related to misconduct after six months. Although learner and educator discipline are totally different the positive principle of progressive discipline promoted in the latter may also be utilised in the former.

- Certain forms of external motivation - receiving rewards like free refreshments at the school tuck shop, discount vouchers from certain shops and parts of the school day free - are widely used at primary schools. It might have a positive effect on the behaviour of the learners, but the educational rationale behind such methods is highly debatable.

\subsection{Values and ideals}

A value-driven approach towards education is a major tool in school discipline. A number of principals mentioned that they actively promote Christian values and life ideals in their schools by building them into their year planning. A specific value is chosen for every term, and the different facets of this value are discussed in hall meetings, Life Orientation classes and through strategically placed posters. Other ways of utilising a value-driven approach are the following:

- Many learners that took part in focus-group sessions are convinced, like educators, that the striving for Christian values and a positive relationship with their Creator are essential for positive interpersonal relationships on which sound discipline can be built. They maintain that no values like respect and a future-oriented life approach can be established outside a Christian commitment.

- The development of learners' self-discipline stands out as the single most prominent ideal among educators. One urban secondary school has based its whole disciplinary policy on this ideal, trying to establish a culture similar to a university. Learners are treated as adults, coming to school only when there are scheduled classes and a sense of trust is created. Learners at this school report that some of their fellow-learners are not capable of handling this responsibility well, and misuse the trust placed in them. This attitude results in poor class attendance, especially in the early morning, with learners only turning up after 
one or more periods have passed. Roll call is not part of the strategy, and consequently learners lose out on valuable academic work time. As part of the ideal of self-discipline, the value of responsibility can be added, according to which learners are encouraged to act responsibly in their relationships and their school activities.

- The research project underlying this article has indicated that the value of respect can be regarded as the crucial "missing link" in most disciplinary cases. A lack of respect is regarded as the main reason for the deterioration of previously well-disciplined individuals, schools and communities. Some learners and many educators mention that this attitude stems from home values where parents do not show respect towards those in authority in the wider community.

- To strive towards excellence is another ideal that was reported by educators. This aim relates to values such as "gentlemanly" behaviour, thoughtfulness and pride in one's work - values that are actively promoted by these schools as life objectives for every learner. They are encouraged to develop excellent interpersonal relationships and deliver excellent academic work. Another aspect of this approach is to promote a future-oriented life approach, which is unfortunately lacking in many learners, especially those in less affluent communities. They tend to live for the moment and do not have any long-term vision for their lives.

- An extremely important element of any value-driven educational approach is that learners should experience that the values are demonstrated in the lives and attitudes of their educators and in the approach of the school towards, among others, discipline. Consistency is also very important. Learners at a specific school, for instance, complained that awards are regularly handed out for academic performance, but no acknowledgement is given for positive, disciplined behaviour. Some schools do not only reward learners who demonstrated academic excellence, but also those who gained only average marks by working above their intellectual ability.

\subsection{Discussion}

In the final analysis, disciplinary problems can only be eradicated by following a positive strategy, i.e. of deliberately educating the learners to become mature and responsible adults. In essence, education consists of four elements, all of which should be present in a strategy for combating learner misconduct, on the one hand, 
and to promote true, responsible and mature adulthood, on the other. The first of these elements is unfolding: reality should be unfolded for a learner, and - conversely - a learner's potential should be unfolded so that he or she becomes able to serve God and fellow human beings to the best of their abilities. The second element is enabling: a learner should be guided and assisted to achieve the skills required for a mature and responsible existence, also in the classroom. The third element, already discussed above, is discipling: learners have to be guided to understand that they should not only hear what God expects from them in His Word (the Bible), but also to be prepared to do His word in their dealings with Him and with their fellow human beings. The fourth element is modelling: the educators, in this case the teachers, should provide their learners with respectable models; they should provide exemplary lives that can be emulated. If the teachers themselves misbehave (come late, are drunk at school, unprepared for their work, disobedient), they can hardly expect their pupils to behave differently.

The responses gleaned from the empirical survey among individuals and focus groups provided valuable and valid insights into forms of learner misconduct and strategies to address the situation. However, apart from relatively vague references to an approach or strategy based on Christian principles and values, most of the responses seemed to touch only on the periphery of the actual problem and of the solution to the problem. The core of the problem is sinful disobedience, to God and His ordinances, and the remedy is education in the four-fold sense discussed above: unfolding, enabling, discipling and modelling.

\section{Conclusion and recommendations}

Results from this research project on learner discipline indicated that the general, traditional trend among educators is to try to get learners to obey rules. Some create many rules and are continually looking for disciplinary measures that would force learners to obey and conform. A more positive approach - stronger relationships with learners, better preparation for classes and the enhancement of values rather than creating more rules - is, however, recommended. Educators should be aware of the root of the problem on the one hand, and also about the four-fold remedy to the problem, as discussed above.

Workshops to inform, motivate and sometimes educate educators, principals and eventually parents should include activities that would 
develop, on the one hand, better disciplinary techniques and on the other, positive, value-driven approaches based on the Christian principles outlined, and that would help ensure learners develop respect, pride, a quest for excellence, self-discipline and a futureoriented life approach. In conclusion, in order to achieve a balanced well-disciplined school society, there should be a greater emphasis on learners' responsibilities and obligations and less on an individual's rights.

\section{Bibliography}

ANDREWS, S.P. \& TAYLOR, P.B. 1998. Evaluation of an alternative discipline program. High School Journal, 81(4):209, April / May.

BOGDEN, R.C. \& BIKLEN, S.K. 1982. Qualitative research for education: An introduction to theory and methods. Boston : Allyn \& Bacon.

BORG, W.R. \& GALL, M.D. 1989. Educational research. An introduction. New York : Longman.

BURGESS, R.G. 1985. Strategies of educational research. Qualitative methods. London : Falmer.

CAREY, E.A. 1984. Themes of adult development in women: Life history interviews with never-married women over sixty. Boston : Boston College. (Ph.D.- thesis.)

DEPARTMENT OF EDUCATION 2000. Alternatives to corporal punishment The learning experience. A practical guide for educators. Pretoria : Sol Plaatje House.

DOE see DEPARTMENT OF EDUCATION

ERASMUS, E. \& JOUBERT, J.J. 1998. Skole het innoverende planne in plek van lyfstraf. Beeld: 10, Febr. 16.

FOWLER, S., VAN BRUMMELEN, H.W. \& VAN DYK, J. 1993. Christian schooling: Education for freedom. Potchefstroom : IRS.

GOETZ, J.P. \& LECOMPTE, M.D. 1984. Ethnography and qualitative design in educational research. London: Academica Press.

HENNING, E. 2004. Finding your way in qualitative research. Pretoria : Van Schaik.

LEMMER, E.M. 1991. Qualitative research methods in comparative education. Subject seminar of the Comp. Ed. interest group of EASA, University of Pretoria, 23 October. p. 1-18.

LEEDY, P.D. \& ORMROD, J.E. 2001. Practical research planning and design. New Jersey : Prentice-Hall.

MABEBA, M.Z. \& PRINSLOO, E. 2000. Perceptions of discipline and ensuing discipline problems in secondary education. SA Journal of Education, 20(1):34-41, Febr.

MAREE, K. 2000. What cannot be endured must be cured: untying the Gordian knot of violence in South African Schools. Acta Criminologica, 13(3):1-13.

MOLOI, P.I.M. 2002. The role of the parents in discipline as an aspect of school safety. Johannesburg : RAU. (M.Ed. mini-dissertation.)

NXUMALO, Z.Z. 2001. The differential analysis of secondary school learners' perception of discipline in Soweto. Johannesburg : RAU. (M.Ed. minidissertation.) 
NGUBANE, P. 2000. Detention, gardening proposed instead of caning. The Star: 5, Oct. 6.

REDDY, K. 1996. Classroom management behaviour as an aspect of order and discipline: implications for the management of teacher competence. SA Johannesburg : RAU. (M.Ed. mini-dissertation.)

see REPUBLIC OF SOUTH AFRICA

REPUBLIC OF SOUTH AFRICA. 1996a. South African Schools Act, Act 84 of 1996. 15 November. Pretoria : Government Printers.

REPUBLIC OF SOUTH AFRICA. 1996b. The Constitution of The Republic of South Africa, Act 108 of 1996. Pretoria : Government Printers.

REPUBLIC OF SOUTH AFRICA. 1998. Employment of Educators Act, Act 76 of 1998. Pretoria : Government Printers.

SCHOEMAN, P.G. 1975. Grondslae en implikasies van 'n Christelike opvoedingsfilosofie. Bloemfontein : SACUM.

VAN BRUMMELEN, H. 1988. Walking with God in the classroom. Burlington : Welch.

VAN DER WALT, B.J. 1994. The liberating message. Potchefstroom : IRS.

VAN DER WALT, J.L. 2004. 'n Beginselgrondslag vir gesag, vryheid, orde en dissipline in die onderwysopset van die vroeg-21ste eeu. Ongepubliseerde manuskrip. Potchefstroom : Fakulteit Opvoedingswetenskappe.

VAN DYK, J. 1997. Letters to Lisa. Conversations with a Christian teacher. Sioux Center : Dordt College Press.

VAN DYK, J. 2000. The craft of Christian teaching. Sioux Center : Dordt College Press.

VAN WYK, N. 2001. Perceptions and practices of discipline in urban black schools in South Africa. SA Journal of Education, 21(3):195-201, August.

VOGELAAR, D. \& BREGMAN, C. 1983. Mens- en kindbeeld in bijbelsreformatorische zin. Hendrik Ido Ambacht : Begeleidingscentrum Gereformeerd Schoolonderwijs.

\section{Key concepts:}

children's rights

learner discipline

learner misconduct - causes of

proactive measures

\section{Kernbegrippe:}

kinderregte

leerderdissipline

leerderwangedrag: oorsake van

proaktiewe maatreëls

\section{Appendix A}

\section{Interviews at schools}

Despatch High School, Despatch, Eastern Cape, 14 August 2002. DF Malan High School, Bellville, Western Cape, 12 August 2002. 
Eversdal Primary School, Durbanville, Western Cape, 12 August 2002.

Groenberg Secondary Skool, Grabouw, Western Cape, 12 August 2002.

Hottentots-Holland High School, Somerset West, Western Cape, 12 August 2002.

Keerom Primary School, Montagu District, Western Cape, 8 August 2002.

Moroka High School, Thaba Nchu, Free State Province, 16 August 2002.

Potchefstroom Gimnasium, Potchefstroom, North West Province, 30 May 2002.

Schoonspruit High School, Klerksdorp, North West Province, 29 May 2002.

Schoonspruit Primary School, Klerksdorp, North West Province, 29 May 2002.

Somerset West Primary School, Somerset West, Western Cape, 12 August 2002.

Stilfontein Primary School, Stilfontein, North West Province, 29 May 2002.

Swellendam High School, Western Cape, 13 August 2002.

W. Thejane Middle School, Thaba Nchu, Free State Province, 16 August 2002.

Field Workers for qualitative study

Riaan Swanepoel, Naomi Swart, Tiana Hendrikse, Heleen van den Berg, Ruben Pieterse, Neil de Beer, Liza Badenhorst, Jana Conradie, Sonja Fourie, Mia van der Westhuizen, Peet Steyn, Wandi Greyling, Henk Kotzé, Lourens Prinsloo.

\section{Appendix B}

Focus-group session: Potchefstroom, 3 December 2002

Educators representing:

Mooirivier Primary School, Potchefstroom

Totius Academy, Potchefstroom

Roshnee Secondary School, Vereeniging. 
